\title{
Inhaled corticosteroids: effects on the airway vasculature in bronchial asthma
}

\author{
G. Horvath*,* and A. Wanner*
}

ABSTRACT: Inhaled corticosteroids suppress airway inflammation and components of airway remodelling in bronchial asthma. In the tracheobronchial (airway) vasculature, these include the inhibition of inflammatory hyperperfusion, microvascular hyperpermeability, mucosal oedema formation, and the formation of new blood vessels (angiogenesis).

Corticosteroids are now known to exert their effects on the airway vasculature through genomic and nongenomic mechanisms. Genomic actions involve the regulation of target genes, and suppress most of the vascular elements of inflammation and angiogenesis in the airway. In contrast, nongenomic actions are mediated by rapid cellular mechanisms, and induce transient vasoconstriction in the airway, thereby reversing inflammatory hyperperfusion.

The vascular actions of corticosteroids contribute to controlling clinical symptoms of asthma primarily by influencing airway calibre in the lung periphery and airway hyperreactivity.

In this review article, recent advances into the understanding of cellular mechanisms and the clinical implications of the interaction of inhaled corticosteroids and the airway vasculature in asthma are reviewed.

KEYWORDS: Airway vascularity, angiogenesis, asthma, inhaled corticosteroids, nongenomic action, vasoconstriction

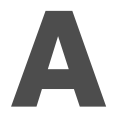
irway inflammation is a central feature of bronchial asthma. In addition to inflammatory cell infiltration in the bronchial wall [1], histological analysis of endobronchial biopsy specimens and new methods of blood flow measurements have revealed prominent alterations of the tracheobronchial (airway) vasculature in patients with asthma. The major structural and functional changes related to the airway circulation include the proliferation of blood vessels (angiogenesis) [2-4], increased blood flow $[5,6]$, increased microvascular permeability $[7,8]$, and oedema formation in the airway wall [9]. These vascular components seem to have significant clinical implications because of their correlations to asthma severity, including airflow limitation [10-13] and bronchial hyperresponsiveness [7, 11, 14-18]. Recent advances in the understanding of the cellular mechanisms responsible for these vascular abnormalities may ultimately lead to new therapeutic approaches for the treatment of asthma.

Since 1949, when HENCH et al. [19] published his findings on cortisone causing dramatic improvements in patients with rheumatoid arthritis, corticosteroids have become established as the most potent anti-inflammatory agents in the pharmacotherapy of various chronic inflammatory diseases, including asthma [20]. The inflammatory process in asthma involves the increased expression of various pro-inflammatory chemokines, cytokines, growth factors, lipid mediators, adhesion molecules, enzymes, and receptors for the same inflammatory mediators [21]. Corticosteroids are the most effective drugs to suppress airway inflammation, mainly by downregulation of pro-inflammatory proteins $[22,23]$. In addition, corticosteroids seem to reverse components of the asthma-induced structural changes (airway remodelling), including the increased vascularity of the bronchial wall [24].

The anti-inflammatory actions of corticosteroids occur with a considerable delay (within hours or days) because of the multiple steps of cellular actions required to change protein expression. However, evidence is now accumulating for rapid corticosteroid actions [25, 26], and the existence of membrane-bound steroid receptors that may mediate these rapid actions [27, 28]. The rapid effects of corticosteroids have also been

\section{AFFILIATIONS}

*Division of Pulmonary and Critical Care Medicine, University of Miami School of Medicine, Miami,

$\mathrm{FL}, \mathrm{USA}$ and

\#Dept of Respiratory Medicine, Semmelweis University Budapest, School of Medicine, Hungary.

\section{CORRESPONDENCE}

A. Wanner

Division of Pulmonary and Critical Care Medicine

University of Miami School of Medicine

P.0. Box 016960 (R-47)

Miami

FL 33101

USA

Fax: 13052436992

E-mail: AWanner@med.miami.edu

Received:

April 212005

Accepted after revision:

July 222005

SUPPORT STATEMENT

$G$. Horvath is a recipient of the Bolyai Fellowship of the Hungarian Academy of Sciences, Budapest, Hungary.

European Respiratory Journal Print ISSN 0903-1936 Online ISSN 1399-3003 
demonstrated in the airway vasculature in recent years $[29,30]$. These "nonclassical" actions might contribute to the antiinflammatory effects of corticosteroids; however, the underlying cellular mechanisms are clearly incompatible with the transcriptionally mediated (genomic) actions.

Here, the current authors provide an overview of the rapidly expanding information on: 1) the molecular basis of the genomic and nongenomic actions of corticosteroids; 2) the vascular manifestations of asthma; and 3) the interactions of corticosteroids and airway blood vessels by which inflammatory changes of the airway vasculature can be reversed in patients with asthma.

\section{GENOMIC MECHANISMS OF CORTICOSTEROID ACTIONS}

Inhaled corticosteroids suppress airway inflammation, which is responsible for asthma-associated changes of the airway vasculature. The anti-inflammatory effects of corticosteroids are due to activation or repression of target genes involved in the inflammatory process (fig. 1). These genomic actions are mediated by intracellular receptors (glucocorticoid receptors; GRs), which ultimately alter transcription through direct DNA binding [31] or transcription factor inactivation [32]. Because genomic mechanisms require additional steps, such as protein synthesis, sorting, modification, and intracellular transport, anti-inflammatory effects of corticosteroids take at least hours to occur.

\section{Gene activation by direct DNA binding (transactivation)}

According to the classical model of steroid hormone action, the lipophilic corticosteroid molecules easily cross the lipid bilayer of the cell membrane to enter into the cell and bind to specific receptors [33]. After corticosteroid binding and dissociation of the two subunits of the heat-shock protein 90 (hsp90), which act as a molecular chaperone, activated GRs translocate to the nucleus and bind to palindromic DNA sequences (response elements) in the promoter regions of target genes. Depending on positive or negative activity of the regulatory elements, binding of the ligand-activated receptor complex may up- or downregulate gene transcription, and thus protein synthesis. Corticosteroids increase the transcription of some antiinflammatory genes through direct DNA binding; however, this mechanism seems to have a minor role in the suppression of inflammation. For instance, corticosteroids have been reported to repress inflammation efficiently in mice with a defective GR, which cannot bind DNA [34]. Recently, it has been proposed that transactivation is responsible for some side effects (e.g. diabetes induction, skin atrophy) caused by corticosteroids [35].

\section{Gene repression by protein-protein cross-talk (transrepression)}

Transcription is upregulated for a variety of inflammatory genes that play a central role in asthma-associated airway inflammation [21]. Increased transcription is induced by proinflammatory transcription factors, such as nuclear factor- $\kappa \mathrm{B}$

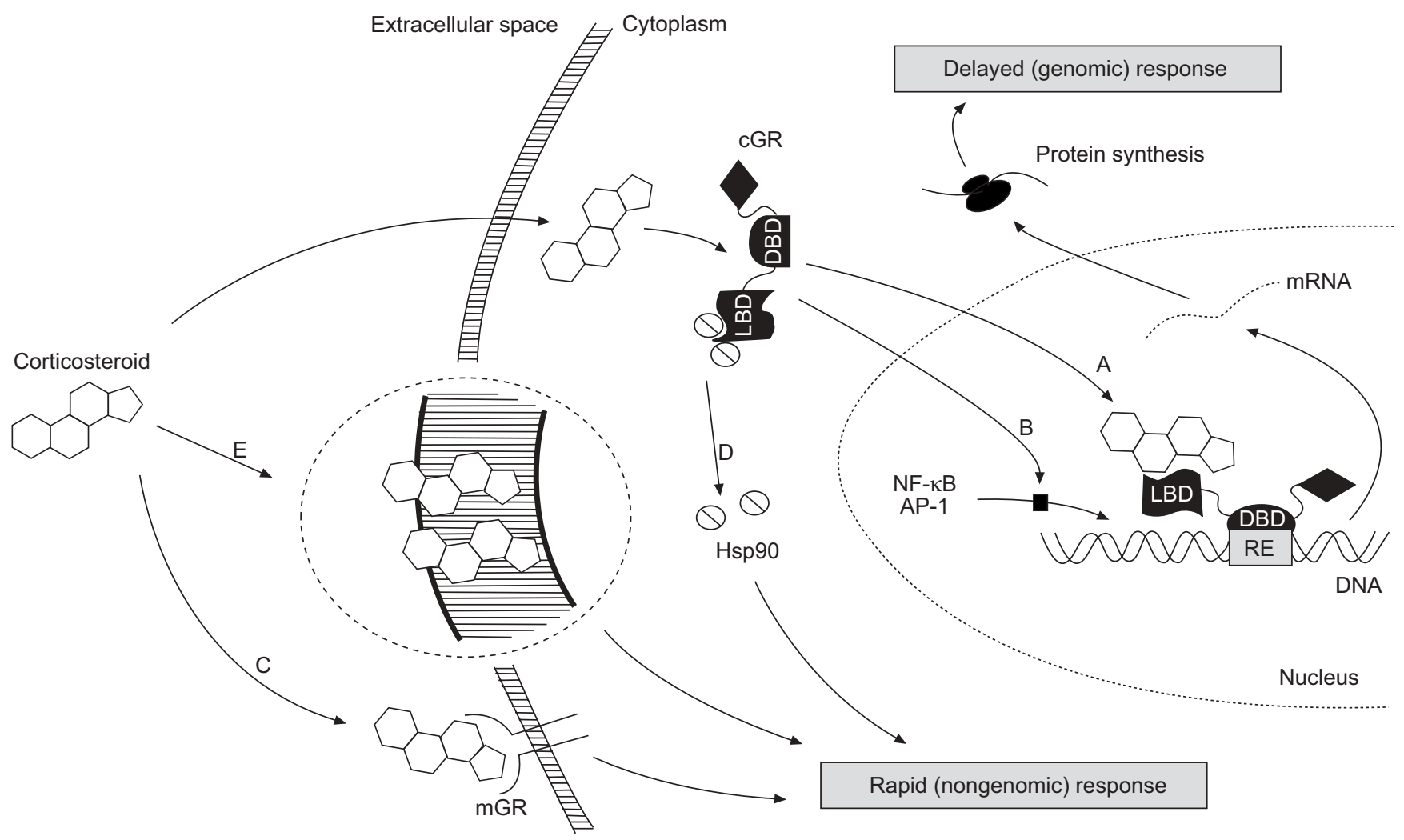

FIGURE 1. Schematic diagram of the complex cellular actions of corticosteroids. Genomic actions are mediated by cytoplasmic receptors, which ultimately alter transcription through A) direct DNA binding or B) transcription factor inactivation. In contrast, nongenomic actions are mediated by C) membrane-bound or D) cytoplasmic receptors, or E) nonspecific interactions with the cell membrane. cGR: cytoplasmic glucocorticoid receptor; mGR: membrane glucocorticoid receptor; LBD: ligand-binding domain; DBD: DNA-binding domain; Hsp90: heat-shock protein 90; RE: response element; NF-kB: nuclear factor-kB; AP-1: activating protein-1. 


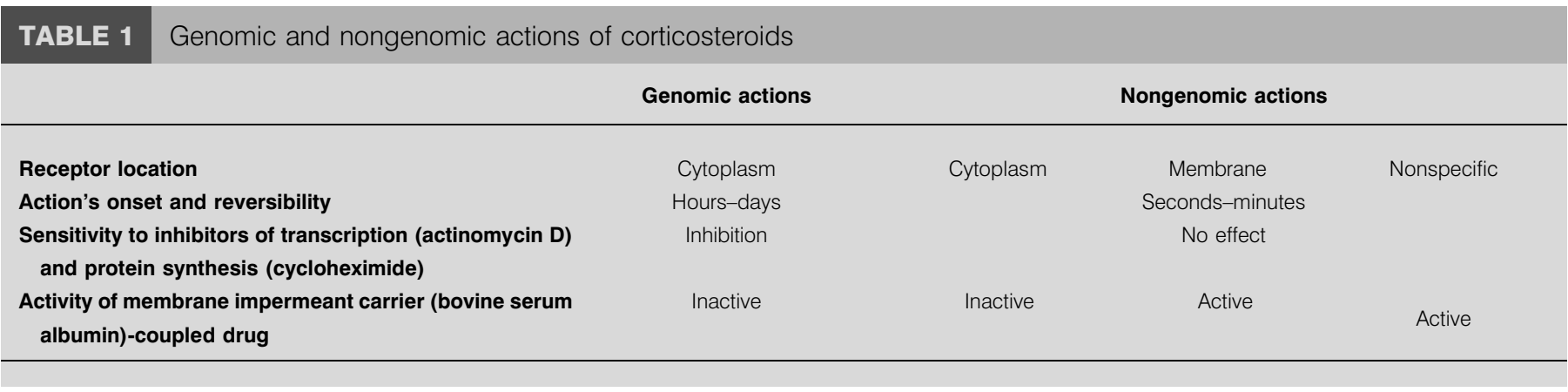

[36] and activating protein-1 [37]. To suppress inflammation, the ligand-activated GR directly binds to the pro-inflammatory transcription factors and interferes with their functions [32]. Transcription factor inactivation results in decreased transcription and synthesis of inflammatory proteins, thereby disrupting the inflammatory process. Transrepression is now considered the principal mechanism by which corticosteroids suppress airway inflammation in asthma. In a search for novel anti-inflammatory drugs with reduced risk of side effects caused by transactivation, several selectively transrepressing compounds are under clinical investigation [38].

\section{Post-transcriptional regulation of gene expression}

Post-transcriptional mechanisms regulate mRNA stability and translation of many pro-inflammatory genes involved in the pathophysiology of asthma [39]. In contrast to major pathways activated in response to inflammatory cellular stimuli to stabilise mRNAs (e.g. p38 mitogen-activated protein kinase [40]), corticosteroids have been shown to increase mRNA degradation, and thus block the production of several of proinflammatory cytokines and other proteins. In fact, steroid hormones were one of the earliest molecules shown to downregulate gene expression by increasing mRNA decay rates. Since then, an increasing number of genes have been shown to be inhibited by corticosteroids through a posttranscriptional mechanism [41]. However, the clinical implications of corticosteroid actions on mRNA stability have not been clarified in asthma [42].

\section{RAPID, NONGENOMIC MECHANISMS OF CORTICOSTEROID ACTIONS}

Although the major anti-inflammatory effects of corticosteroids are due to transcriptional mechanisms, evidence is growing for actions manifested within seconds or minutes. These effects are mediated by cellular mechanisms that are too rapid to involve gene expression and have been termed nongenomic actions [43]. Nongenomic actions are initiated by specific interactions with membrane-bound or cytoplasmic GRs, or nonspecific interactions with the cell membrane (fig. 1). Despite a high mechanistic diversity among different cell types, nongenomic actions have some common features (table 1).

In contrast to genomic actions, much less is known about the clinical significance of rapid nongenomic actions of corticosteroids. In bronchial asthma, inhaled fluticasone propionate has been shown to acutely decrease airway mucosal blood flow $[29,44]$, inhibit inhaled AMP-induced bronchoconstriction [45], and protect against exercise-induced bronchial obstruction in children [46]. Corticosteroids have also been shown to acutely decrease nasal itching in allergic rhinitis [47]. In keeping with early reports of acute potentiation of bronchodilator actions by corticosteroids $[48,49]$, budesonide acutely enhanced the fast onset of bronchodilator action of formoterol in patients with chronic obstructive pulmonary disease in a recent study [50]. Although rapid effects on airflow limitation have also been suggested in patients with acute asthma [51], there is insufficient evidence that inhaled corticosteroid therapy results in clinically important rapid changes in pulmonary function [52], whereas systemic corticosteroids probably require $>6 \mathrm{~h}$ to $24 \mathrm{~h}$ to improve pulmonary function [53].

\section{Membrane receptor-initiated actions}

Corticosteroids induce a number of rapid cellular effects without entering into the cell. In some cases, these cell membrane-initiated actions are also sensitive to blockers of the cytoplasmic GR. These observations ultimately resulted in the discovery of corticosteroid binding sites and receptors associated with the cell membrane. After the early demonstration of high-affinity cell membrane binding sites for corticosteroids in rat liver [54], membrane-bound receptors have been shown in amphibian brain [55] and mouse lymphoma cells [56]. Membrane-bound GRs are also present in various human cells, including leukaemic [57] and peripheral blood mononuclear cells [28]. Recently, membrane binding sites for corticosteroids have been demonstrated in smooth muscle cells isolated from human airway blood vessels [58, 59]. Ligand binding to this membrane receptor might be responsible for the hormone's inhibitory effect on norepinephrine uptake into these cells [60].

The molecular structure of the membrane GR is still unknown. Receptor distribution analysis suggests that the same receptor may function in both nuclear and membrane locations [27]. The membrane receptor turned out to be a modified form of the classical GR in some cases of neuronal cells [61]. In contrast, overexpression of His-tagged cytoplasmic receptors did not increase expression of membrane receptors in a recent study [28], which suggests that these are not interchangeable receptor populations. Supporting the existence of distinct receptor proteins, the amphibian brain neuronal membrane receptor has been identified as an acidic glycoprotein with an apparent molecular weight of $63 \mathrm{kD}$ [62], which is inconsistent with the characteristics and predicted weight (i.e. $96 \mathrm{kD}$ ) of the cytoplasmic GR protein. Membrane receptor activation has been shown to induce rapid effects on a variety of second 
messenger systems $\left(\mathrm{Ca}^{2+}\right.$, adenosine $3^{\prime}, 5^{\prime}$-monophosphate, inositol trisphosphate, protein kinase C) to alter cellular processes [63, 64]. In addition to membrane-associated receptors, corticosteroids could bind other receptors, ion channels, enzymes, transporters, and previously undescribed proteins in the cell membrane [27].

\section{Intracellular receptor-initiated actions}

Activation of the cytoplasmic GRs has been shown to initiate rapid nongenomic actions. Following ligand binding, heatshock proteins (e.g. hsp90) and kinases of the mitogenactivated protein kinase system (e.g. Src) are rapidly released from the GR-chaperone protein complex, and the released proteins are thought to induce rapid cellular responses [65]. For instance, heat-shock proteins appear to mediate dexamethasone-induced increase in calcineurin activity of renal ducts [66], whereas Src proteins have been reported to be responsible for dexamethasone-induced inhibition of phospholipase $\mathrm{A}_{2}$ in lung adenocarcinoma cells [67]. Ligand binding of the cytoplasmic GR also leads to rapid activation of the nitric oxide (NO) synthase in endothelial cells; a mechanism by which acute administration of pharmacological doses $\left(40 \mathrm{mg} \cdot \mathrm{kg}^{-1}\right)$ of dexamethasone seem to decrease vascular inflammation and reduce myocardial infarct size following ischaemia and reperfusion injury in mice [68].

\section{Nonspecific actions}

Corticosteroids may cause rapid effects by changing the physicochemical properties of the cell membrane. The lipophilic corticosteroid molecules intercalate into the phospholipid bilayers of cellular membranes. At high concentrations, corticosteroids tend to accumulate in membranes, change membrane fluidity, and thus induce rapid changes in cellular functions [69]. Since membrane fluidity effects require corticosteroid concentrations $>10^{-4} \mathrm{M}$, the functional importance of this mechanism is highly questionable. Corticosteroid intercalation in the cell membrane, however, could influence the function of integral proteins (i.e. ion channels, transporters, and receptors) well below this concentration range [61]. For instance, membrane intercalation of corticosteroids alters membrane transport of cations and increases the proton leak of the mitochondria [70]. In smooth muscle cells isolated from human bronchial arteries, corticosteroids acutely inhibit the uptake of organic cations (or extraneuronal uptake) [60]; this is critical in norepinephrine inactivation in the airways [71]. This rapid nongenomic action is likely to increase the duration of the norepinephrine/vasoconstrictor signal, and consequently decreases airway blood flow as seen in healthy and asthmatic subjects after inhalation of corticosteroids [29]. A similar phenomenon, inhibition of norepinephrine uptake into glial cells in the brain, is proposed to enhance the accumulation of norepinephrine in the synapse, and may speed up the clinical effects of norepinephrine reuptake inhibitor antidepressant drugs [72].

\section{THE AIRWAY VASCULATURE IN PATIENTS WITH ASTHMA}

In addition to serving as the source of nutrients to the bronchial wall [73], the airway circulation has important roles in heat and water exchange [74, 75], airway hyperreactivity
$[7,14,17,76]$, and possibly the regulation of airway calibre in the lung periphery [10-13, 77-80]. Furthermore, the airway circulation functions as the conduit for inflammatory cell recruitment [81, 82], and participates in the clearance of locally released, biologically active substances $[83,84]$ and inhaled materials transported from the surface to the deeper tissue [85].

As an airway disease characterised with continuous inflammation and repair processes simultaneously, asthma is known to lead to both functional (vasodilation, hyperperfusion, increased microvascular permeability, oedema formation, and inflammatory cell recruitment) and structural changes (angiogenesis) in the airway vasculature. The vascular changes have significant pathophysiological consequences, and thus likely participate in the clinical manifestations of asthma [86, 87]. Despite the complex actions of inflammatory mediators, neurotransmitters, and neuropeptides on vascular endothelial and smooth muscle cells, the cellular mechanisms leading to the vascular manifestations of asthma have not been completely clarified.

\section{Increased blood flow}

Hyperaemia and hyperperfusion are consistent features of inflammation. Asthma, therefore, is expected to be associated with an increased airway blood flow. In the atopic sheep model of asthma, inhalation challenge with antigen has been shown to cause increases in airway blood flow, which were related to inflammatory mediators [88-90]. Using a recently invented noninvasive method for airway blood flow measurements, these findings subsequently have been confirmed in human subjects. By measuring the uptake of an inhaled, soluble inert gas (dimethyl ether) [91, 92], airway mucosal blood flow (comprising $\sim 70 \%$ of total airway blood flow) has been shown to be increased in patients with stable bronchial asthma [5, 29, 93, 94]. Calculated as in the volume of the conducting airways from the trachea to the terminal bronchioles (disregarding the most proximal $50 \mathrm{~mL}$ ), mean airway blood flow values were $24-77 \%$ higher in asthmatics than in healthy controls $[5,94]$.

In the asthmatic airway, increased blood flow is due to dilatation of resistance arteries and increased number of vessels. In animal models, most inflammatory mediators cause vasodilation [73]. Histamine has a triphasic effect with an initial vasodilation followed by vasoconstriction, and then a long-lasting vasodilation. Sensory neuropeptides released from afferent nerves are also strong vasodilators [95]. Despite the apparent vasodilation, some mediators released in the airways of asthmatics are vasoconstrictors, including endothelin-1 [96], which seems to be negatively regulated by pro-inflammatory tumour necrosis factor- $\alpha$ [97]. Further studies are required to reveal the contribution of airway hypervascularity to increased airway blood flow in asthmatics.

\section{Abnormalities of blood flow regulation}

The sympathetic nervous system provides local control of airway blood flow by releasing norepinephrine, which causes vasoconstriction through activation of $\alpha_{1}$-adrenoreceptors on vascular smooth muscle [98-100]. The $\alpha_{1}$-adrenergic responsiveness of airway blood flow has been confirmed in vivo, and additionally shown to be potentiated in asthmatics [94]. This airway vascular hyperresponsiveness, which has also been 
reported in animal models of atopy [99], is similar to the bronchial hyperresponsiveness to $\alpha$-adrenergic agonists seen in asthmatics [101]. The possible mechanisms of asthmaassociated vascular hyperresponsiveness include increased expression and function of $\alpha$-adrenoceptors, altered signal transduction, impaired inactivation of $\alpha$-adrenergic agonists by cellular uptake processes, or a combination thereof [102, 103]. A putative endothelial contractile factor has also been proposed to be responsible for the increased vascular sensitivity to $\alpha_{1}$-adrenergic agonists [99].

Although $\beta_{2}$-adrenergic agonists cause vasodilation in the bronchial circulation predominantly through increased synthesis of endothelial NO [104, 105], recent studies disclosed blunted $\beta_{2}$-adrenoreceptor-mediated airway vasodilation in asthmatics [94, 106]. In addition to impaired signal transduction or decreased expression of $\beta$-adrenergic receptors [102], the attenuation of the $\beta_{2}$-adrenergic agonist-induced vasodilation might be due to maximal vasodilation reached in response to airway inflammation [5].

\section{Increased vascular permeability}

Microvascular hyperpermeability and oedema formation are common features of inflammation. In patients with allergic asthma, inhalation of the allergen produces both immediate and late-phase inflammatory responses during which plasma extravasation occurs from the airway microcirculation [107109]. Asthma-associated plasma leakage is believed to occur largely through the formation of intercellular gaps between otherwise tightly associated endothelial cells in postcapillary venules [110-112]. Extravasated plasma can pass the epithelium, collect in the airways, compromise epithelial integrity and ciliary function, and thereby contribute to excessive airway secretions to form luminal mucus plugs [113]. Plasma leakage can also lead to mucosal oedema and bronchial wall swelling, which could reduce airway calibre and cause airflow limitation [80]. In addition, increased microvascular permeability may contribute to bronchial hyperresponsiveness in asthma $[8,18]$.

Plasma extravasation is considered as a specific response to the asthma-associated inflammatory insult involving the release of inflammatory mediators, growth factors, neuropeptides, eosinophil granule proteins, cytokines, and proteases in the airway [109, 114]. Histamine, platelet-activating factor, leukotriene $\mathrm{D}_{4}$ and bradykinin can increase microvascular permeability through the formation of intercellular gaps [115-118]. The induced sputum levels of vascular endothelial growth factor (VEGF), which has been shown to cause fenestration of endothelial cells [119], are increased [120] and correlate with airway vascular permeability in patients with asthma [8, 121]. In contrast to findings in rodents $[122,123]$, the phenomenon of "neurogenic inflammation" seems to have a minor role in increased permeability in asthma because inhalation of the irritant capsaicin that activates unmyelinated sensory nerves to release inflammatory neuropeptides (i.e. substance $\mathrm{P}$ and calcitonin gene-related peptide) evokes no exudation of plasma in the airway in humans [124]. In addition to inflammatory exudative agents, vasodilation and microvascular congestion have been shown to increase microvascular permeability [125]. Recently, blood vessels newly generated in chronic airway inflammation have been shown to be leaky, immature, and unstable [3], which may contribute to increased vascular permeability in asthma.

\section{Inflammatory cell recruitment}

The vascular manifestations of asthma include the influx of leukocytes from the airway microcirculation into the extravascular tissues [81, 82]. The recruitment of leukocytes is directed mainly by the inflammation-associated release of peptide chemokines [126] and lipid mediators, such as leukotriene $\mathrm{B}_{4}$ and prostaglandin $\mathrm{D}_{2}$ [127]. Specific subsets of cell adhesion molecules on both leukocytes and endothelial cells are responsible for the different steps of leukocyte extravasation [128]. The major steps of vascular transmigration of leukocytes are generally known as leukocyte rolling along the endothelial surface, activation by inflammatory chemoattractants, binding to endothelial intercellular adhesion molecules, extravasation, and chemotaxis to sites of inflammatory tissue damage [129, 130]. While inflammation causes endothelial gaps and plasma leakage in postcapillary venules, leukocyte migration mostly occurs in collecting venules in the airway [111].

\section{Angiogenesis and microvascular remodelling}

The airway circulation is known to proliferate in a variety of pathological conditions. In addition to pulmonary artery occlusion [131], lung abscess [132], pulmonary tuberculosis [133], and lung tumours [134], the airway circulation has been shown to undergo structural changes in chronic inflammatory airway diseases [135]. Chronic inflammation leads to the growth of new blood vessels from existing ones (angiogenesis) and the alterations of the existing blood vessels (microvascular remodelling). In patients with asthma, early histological studies showed that the abnormally thick bronchial mucosa contains enlarged and congested blood vessels [136, 137]. Since then, a number of studies have demonstrated increased vascularity (i.e. size and number of vessels, or cross-sectional vascular area) of the bronchial mucosa in patents with asthma [10-13, 15-17, 138-141]. Asthma-associated inflammation also results in functionally altered blood vessels as indicated by abnormalities of airway blood flow regulation $[29,94]$.

A variety of growth factors, cytokines, chemokines, enzymes, and other factors (e.g. hypoxia) have been reported to induce angiogenesis [142], but their respective roles have not been clearly defined in asthma. Because the airway levels of VEGF are increased in asthma, directly correlate with airway mucosal vascularity, and inversely correlate with airway function and hyperreactivity [7, 15, 16, 120], VEGF may be a critical regulator of new vessel formation in asthma. Furthermore, in lung-targeted transgenic mice, selective overexpression of VEGF induced an asthma-like phenotype with vascular remodelling (angiogenesis, hyperpermeability, oedema formation) [143] and extravascular remodelling (mucus metaplasia, myocyte hyperplasia, airway hyperresponsiveness) in the airways [144]. In addition, tumour necrosis factor- $\alpha$, transforming growth factor- $\alpha$, interleukin-8 [145], matrix remodelling proteases [146], stromal cell-derived factor-1 [140], basic fibroblast growth factor [147], and angiogenin [16] have all been proposed to have some role in angiogenesis and microvascular remodelling in asthma. 


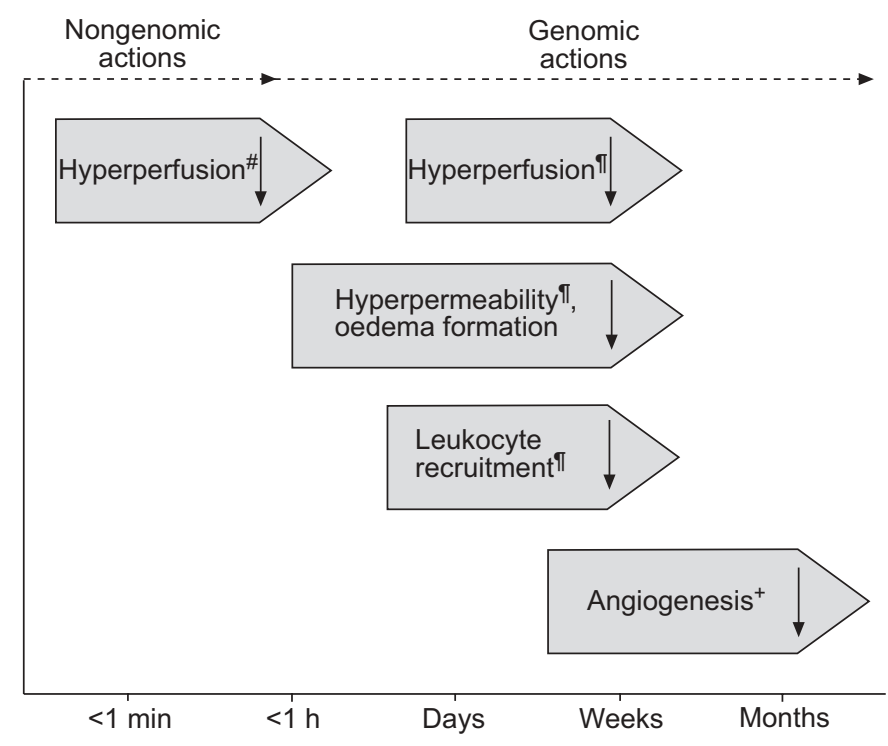

FIGURE 2. Rapid $\left({ }^{\#}\right)$, delayed $\left(^{(*)}\right.$, and long-term $\left(^{+}\right)$vascular effects of inhaled corticosteroids in the airway of patients with asthma. Effects are spaced vertically on the $y$-axis simply to facilitate reading.

The enlarged and congested blood vessels of the airway mucosa contribute to increased airway wall thickness in asthma and, therefore, are potential contributors to airflow limitation and airway hyperresponsiveness [80]. A correlation between airway vascularity and airway hyperresponsiveness has been found in asthmatic subjects [11, 15, 16]; whether a cause-effect relationship exists remains to be demonstrated.

\section{RAPID EFFECTS OF CORTICOSTEROIDS ON THE AIRWAY VASCULATURE}

Corticosteroids exert rapid, delayed, and long-term effects on the airway vasculature in asthma (fig. 2). Among these effects, corticosteroids have been shown to acutely (within minutes) alter vascular tone through nongenomic cellular actions. In 1962, McKenzie and Stoughton were the first to report that corticosteroids applied on the skin cause blanching due to local vasoconstriction [148]. Although skin blanching after topical corticosteroids takes several hours to appear, intradermal injection of corticosteroids induces blanching within an hour, which suggests a nongenomic action. A similar phenomenon has been reported recently in the rat sciatic nerve [149] and the human bronchial mucosa [29]. Corticosteroids have also been shown to acutely enhance responses to vasoconstrictors in several systemic vascular beds, including radial [150], coronary [151], ophthalmic [152], and bronchial arteries [153]. Furthermore, corticosteroids may acutely (within $60 \mathrm{~min}$ ) restore vasoconstrictor responses to norepinephrine in patients with medical conditions of impaired production of endogenous corticosteroids [154], and in experimental adrenalectomy [155].

\section{Reduction of airway blood flow}

Inhaled corticosteroids have been shown to acutely suppress airway hyperperfusion associated with asthma. A single dose of inhaled fluticasone propionate has been shown to decrease airway mucosal blood flow in healthy and asthmatic subjects with a maximal effect $\sim 30 \mathrm{~min}$ after inhalation, and a return to baseline at $90 \mathrm{~min}$ [29]. The blood flow effect increased in a dose-dependent manner up to $880 \mu \mathrm{g}$ of fluticasone propionate, with a significantly greater effect in asthmatics than in healthy controls. The acute vasoconstrictor action has also been demonstrated after inhalation of beclomethasone dipropionate and budesonide [44].

To date, evidence suggests that corticosteroids decrease airway blood flow by modulating norepinephrine-mediated (sympathetic) control of vascular tone. Pretreatment with $5 \mathrm{mg}$ terazosin, which is a selective $\alpha_{1}$-adrenoreceptor antagonist, inhibited the effect of fluticasone propionate on blood flow [153], suggesting that corticosteroids facilitate noradrenergic signal transmission to induce neurogenic vasoconstriction. There are many possible mechanisms to facilitate noradrenergic signal transmission [156]. In essential hypertension, impaired neuronal uptake of norepinephrine has been proposed to be responsible for the increased sympathetic tone [157]. Conversely, corticosteroids are known to acutely inhibit the extraneuronal uptake of norepinephrine [158], thereby increasing sympathetic signal transmission [159] and vascular tone [160]. In the airway, corticosteroids inhibit the extraneuronal monoamine transporter-mediated uptake of norepinephrine by bronchial arterial smooth muscle cells $[58,60]$. This rapid effect reduces the removal of norepinephrine released from airway nerves and, therefore, may be responsible for the $\alpha_{1}$-adrenoreceptor-dependent vasoconstrictor action of corticosteroids (fig. 3). Furthermore, the impaired extraneuronal uptake of norepinephrine in atopy, as demonstrated in ovalbumin-sensitised rabbits [103], might result in increased vasoconstrictor responsiveness to corticosteroids as seen in asthmatic subjects [29]. Corticosteroids are also expected to rapidly increase the pharmacological actions of cationic drugs inactivated by the extraneuronal uptake [161]. This notion is supported by the finding that inhaled fluticasone propionate acutely potentiates the vasoconstrictor effect of an inhaled $\alpha_{1}$-adrenergic agonist [153].

Alternatively, the acute vascular effects of corticosteroids may involve other nongenomic actions, such as the rapid stimulation of phosphoinositide breakdown to increase intracellular inositol 1,4,5-triphosphate levels [162], the protein kinase Cdependent activation of the cell membrane $\mathrm{Na}^{+} / \mathrm{H}^{+}$exchanger [163], and calcium mobilisation in the cytoplasm of vascular smooth muscle cells [164].

\section{Other rapid effects}

Corticosteroids could disrupt the inflammatory process through rapid inhibitory actions on cellular processes or mediators related to inflammation [65, 165, 166]. For instance, corticosteroids have been shown to rapidly inhibit the release of proteolytic enzymes by stabilising the rat liver lysosomal membranes [167], the epidermal growth factor-stimulated phospholipase $\mathrm{A}_{2}$ activity and arachidonic acid release in A549 human adenocarcinoma cell line $[67,168]$. They also inhibit cation cycling across the cell membrane and respiration in lymphocytes activated by the mitogen concanavalin A [169], phagocytosis and superoxide anion production in macrophages [170, 171], endothelial cell activation and leukocyteendothelial interactions [165], and degranulation of peripheral blood neutrophils [172]. The rapid inhibition of the inflammatory reactions could reduce asthma-associated microvascular hyperpermeability, oedema formation, and inflammatory cell 
TABLE 2 Potentially vasoactive genes and their regulation by corticosteroids in vascular smooth muscle and endothelial cells

\begin{tabular}{|c|c|c|}
\hline \multirow[t]{4}{*}{ Vascular smooth muscle cells } & $\alpha_{1 \beta}$-Adrenergic receptor [177] & $\mathrm{Na}^{+} / \mathrm{Ca}^{2+}$ ATPase [178] \\
\hline & Vasopressin $V_{1 A}$ receptor [181] & \\
\hline & NPR-A [182] & \\
\hline & ACE [183] & \\
\hline \multirow[t]{4}{*}{ Endothelial cells } & ACE [186] & eNOS [187] \\
\hline & & CAT-1 [188] \\
\hline & & Phospholipase $A_{2}$ [189] \\
\hline & & COX-2 [190] \\
\hline
\end{tabular}

$\mathrm{AT}_{1}$ : angiotensin II type 1; NPR: natriuretic peptide receptor; ACE: angiotensin-converting enzyme; eNOS: endothelial nitric oxide synthase; CAT-1: cationic amino acid transporter-1; COX-2: cyclooxygenase type 2 .

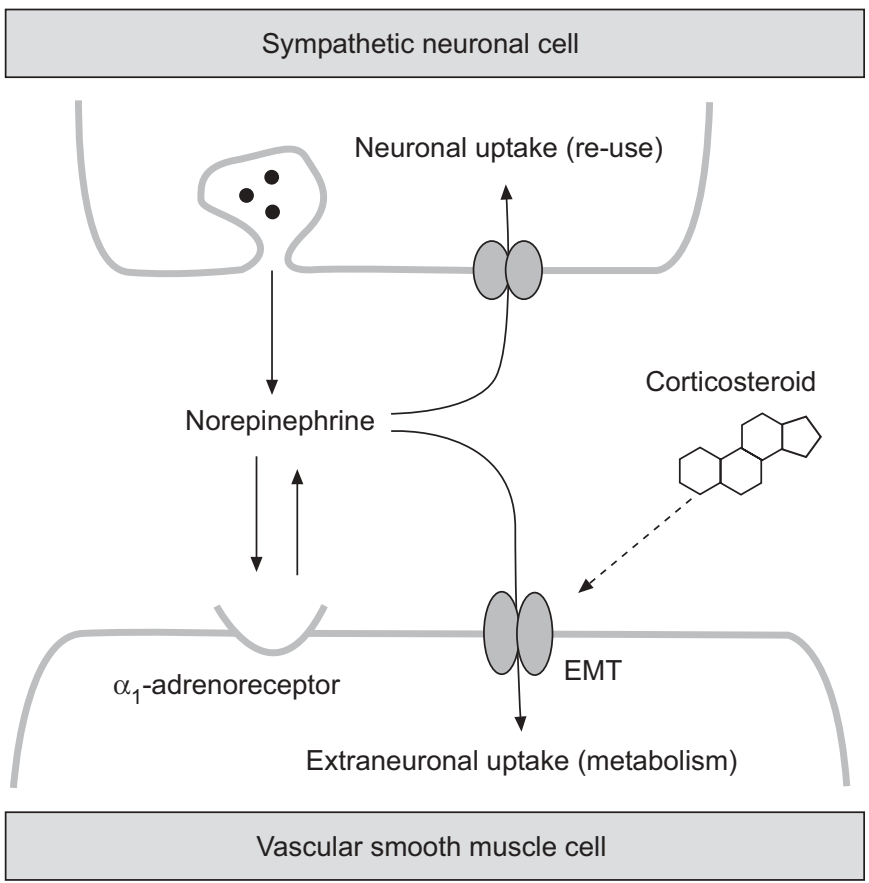

FIGURE 3. Proposed mechanism of the acute vasoconstrictor effect of inhaled corticosteroids in the airway. Corticosteroids facilitate the noradrenergic (sympathetic) neuromuscular signal transmission by rapidly (within $5 \mathrm{~min}$ ) inhibiting the extraneuronal monoamine transporter (EMT) in vascular smooth muscle cells.

recruitment in the airways; however, these acute effects of corticosteroids are poorly documented in patients with asthma.

\section{DELAYED EFFECTS OF CORTICOSTEROIDS ON THE AIRWAY VASCULATURE}

Corticosteroids interact with the vasculature to maintain and, in excess, enhance vascular tone [173]. Impaired production of endogenous corticosteroids in various medical conditions (e.g. acute adrenal insufficiency) is commonly associated with systemic hypotension. In contrast, corticosteroid administration or overproduction of endogenous corticosteroids (e.g.
Cushing's syndrome) is thought to induce systemic hypertension, partially by increasing peripheral vascular tone. The vascular effects are largely mediated through genomic mechanisms, and thus occur with a delay of hours or days.

In asthma, inhaled corticosteroids have been shown to counteract all the vascular manifestations of airway inflammation by acting directly on vascular smooth muscle or endothelium, or indirectly by inhibiting the release of vasoactive inflammatory mediators $[174,175]$. Because disease severity seems to correlate with airway vascular changes in patients with asthma, these genomic vascular actions of inhaled corticosteroids may be of therapeutic value and have recently received increased interest [176].

\section{Reduction of airway blood flow}

A number of studies have demonstrated that inhaled corticosteroid therapy decreases airway mucosal blood flow in patients with asthma. In a cross-sectional study, airway mucosal blood flow was higher by $\sim 23 \%$ in corticosteroidnaïve than in corticosteroid-treated asthmatics [5]. In interventional studies, inhaled fluticasone propionate $\left(440 \mu \mathrm{g} \cdot \mathrm{day}^{-1}\right)$ therapy for 2 weeks reduced blood flow by $\sim 12 \%$ and $21 \%$ in two different groups of asthma patients [6,93], and additionally showed that airway blood returns to the pretreatment level 2 weeks after cessation of therapy.

Corticosteroids are believed to decrease blow flow in the airway mucosa by suppressing inflammation and the release of vasodilator mediators. This was supported by the fact that the effect of inhaled fluticasone propionate $\left(440 \mu \mathrm{g} \cdot \mathrm{day}^{-1}\right)$ was similar to the leukotriene modifier montelukast $\left(10 \mathrm{mg} \cdot \mathrm{day}^{-1}\right)$, to decrease airway blood flow in a 2-week treatment period in asthma patients [6]. Corticosteroids may also act directly on both vascular smooth muscle and endothelial cells (table 2), thereby increasing vascular tone and reducing blow flow in the airway vasculature. In endothelial cells, corticosteroids have been shown to decrease the availability of the potent vasodilator NO [187], possibly by inhibiting the endothelial NO synthase activity [188] or by enhanced NO elimination through the overproduction of reactive oxygen species [191]. 
In vascular smooth muscle cells, corticosteroids enhance responses to endogenous vasoconstrictors through multiple mechanisms. Among others, these may include the increases in receptor expression [179], transmembrane signalling by receptor-G protein coupling [192], calcium influx [193], and calcium sensitivity of contractile proteins [194].

\section{Effects on blood flow regulation}

Initial reports indicate that corticosteroids can restore vascular responsiveness to adrenergic agonists [94], in keeping with the observations on impaired adrenergic responsiveness of bronchial smooth muscle. Whereas the $\beta_{2}$-adrenoreceptor-mediated airway vasodilation is blunted in corticosteroid-naive asthmatics $[94,106]$, the vasodilator effect of inhaled albuterol was present in asthmatic patients on inhaled corticosteroid therapy [5]. The vasodilator response to inhaled albuterol was also restored by a 2-week treatment with inhaled fluticasone propionate $\left(440 \mu \mathrm{g} \cdot \mathrm{day}^{-1}\right)$ [93]. Currently, there are no reports available on the effects of inhaled corticosteroid therapy on $\alpha_{1}$-adrenergic vascular hyperresponsiveness seen in asthma patients.

\section{Inhibition of oedema formation}

Corticosteroids suppress increased microvascular permeability and oedema formation associated with airway inflammation. In the rat trachea, dexamethasone treatment reduced plasma extravasation produced by mediators of the neurogenic inflammation, such as tachykinins and substance P [195]. In ovalbumin-sensitised rats, dexamethasone treatment reduced protein extravasation in response to allergic inflammation caused by exposure to ovalbumin [118]. In patients with asthma, inhaled corticosteroid therapy has been shown to suppress the increased microvascular permeability and plasma leakage into the airway lumen, as determined by measuring concentrations of high molecular weight proteins (e.g. $\alpha_{2}$-macroglobulin) in induced sputum $[121,196]$ and bronchoalveolar lavage fluid [14, 197]. Because increased microvascular permeability has a role in asthma-associated airflow obstruction, the anti-permeability actions of corticosteroids may be of therapeutic value.

In neurogenic inflammation, the inhibitory effects of corticosteroids are likely to be mediated by neutral endopeptidase and angiotensin-converting enzyme, since dexamethasone's action was completely reversed by inhibiting these tachykinindegrading enzymes [198]. To inhibit airway extravasation of plasma proteins, dexamethasone seems to block mast cell degranulation, and thus the release of leukotrienes $\mathrm{B}_{4}$ and $\mathrm{C}_{4}$ in the airways of ovalbumin-sensitised rats in response to antigen challenge [118]. In a recent study of asthmatic subjects treated with inhaled beclomethasone dipropionate $\left(800 \mu \mathrm{g} \cdot \mathrm{day}^{-1}\right)$, a significant correlation has been found between the reduction of airway vascular permeability and induced sputum VEGF levels [8]; this is consistent with the notion, but not definite proof, that inhaled corticosteroids might reduce airway microvascular hyperpermeability by decreasing airway levels of VEGF, a potent stimulator of vascular permeability.

\section{Inhibition of inflammatory cell recruitment}

Leukocyte and endothelial cell adhesion molecules are critically involved in leukocyte extravasation from the bloodstream into the surrounding peribronchial tissue in inflammatory airway diseases and, therefore, these molecules are generally considered as targets for anti-inflammatory therapeutic interventions [128]. By interfering with these key molecules of the recruitment cascade [199], corticosteroids inhibit leukocyte emigration from post-capillary venules into the extravascular matrix, thereby reducing inflammatory cell infiltration in the airway wall [24]. Corticosteroids are known to interfere with leukocyte and endothelial cell adhesion molecules through multiple mechanisms [165]; however, these are incompletely elucidated in asthma. Genomic actions have been shown decrease the expression of a variety of adhesion molecules (e.g. intracellular adhesion molecule 1 and 3, Eselectin, vascular cell adhesion molecule 1, lymphocyte function-associated antigen) involved inflammatory cell recruitment in the airways in asthma [22, 199, 200]. Corticosteroids can also suppress the production of cytokines and chemokines responsible for increased expression of adhesion molecules associated with inflammatory conditions [201, 202]. Additionally, corticosteroids have been proposed to induce the synthesis of such anti-inflammatory mediators (e.g. annexin I), which inhibit the functions of cell adhesion molecules [165].

\section{LONG-TERM EFFECTS OF CORTICOSTEROIDS ON THE AIRWAY VASCULATURE}

Current therapeutic approaches to suppress airway inflammation may not control all symptoms of asthma. Thus, attention has focused on inflammation-associated structural changes in the airway (collectively termed airway remodelling) in recent years. The morphological changes have been implicated in accelerated respiratory function deterioration, irreversible or partially reversible airflow obstruction, and persistent bronchial hyperreactivity seen in some patients with asthma [203, 204]. However, which elements of airway remodelling cause airflow obstruction and airway hyperreactivity and the magnitude of these effects remain subject to debate.

Among other asthma-associated structural alterations in the airway mucosa, quantitative (angiogenesis) and qualitative (microvascular remodelling) changes of airway blood vessels seem to correlate with disease severity, including lung function $[12,13]$ and bronchial hyperreactivity [11, 16, 18]. Thus, morphological changes of the airway vasculature are now being considered as potential targets for therapeutic intervention; however, their roles in the pathophysiology of asthma are still speculative.

\section{Regression of airway blood vessels}

Corticosteroids have a potential therapeutic role of reversing components of airway remodelling in asthma. This has been tested in some recent studies using monoclonal antibodies against type IV collagen to identify blood vessel in bronchial specimens obtained from asthmatic patients. In a crosssectional study, therapy with inhaled beclomethasone dipropionate has been shown to be associated with a reduced area of the lamina propria occupied by vessels; however, the number of vessels decreased only in patients on high doses $\left(\geqslant 800 \mu \mathrm{g} \cdot \mathrm{day}^{-1}\right)$ of the inhaled corticosteroid [11]. Based on interventional studies, the inhaled daily doses and the length of therapy seem to be the critical determinants of the vascular 
effects of inhaled corticosteroids. Furthermore, the inhibitory effects on the remodelling process seem to occur only with long-term therapy with corticosteroids. Whereas a 6-month treatment with a daily dose of $800 \mu \mathrm{g}$ beclomethasone dipropionate reduced the number of blood vessels and the vascular area [139], a 6-week treatment with fluticasone propionate was only effective at a daily inhaled dose of $1000 \mu \mathrm{g}$, and not at $200 \mu \mathrm{g}$, to reduce significantly the number of blood vessels and the vascular area [17]. Moreover, in patients with asthma receiving a daily dose of $400-1000 \mu \mathrm{g}$ of inhaled corticosteroid (beclomethasone dipropionate or budesonide), adding of a daily dose of $200 \mu \mathrm{g}$ fluticasone propionate has not shown any effect on airway vascularity [205].

The inhibitory effects of long-term therapy with inhaled corticosteroids on airway angiogenesis presumably involve the suppression of angiogenetic factors associated with airway inflammation; however, these still need to be explored.

\section{CLINICAL IMPLICATIONS}

Recent studies suggest that inhaled corticosteroids have important roles in the regulation of airway vascular tone, permeability, and structure in patients with asthma. These vascular effects of corticosteroids on airway blood vessels can be expected to have diagnostic and therapeutic implications in the management of asthma [176].

Despite the growing appreciation of the genomic and nongenomic mechanisms that underlie vascular actions, there remain significant gaps in the understanding of the patterns of corticosteroid actions and their effects on the pathophysiology of asthma, including disease severity and persistence. Furthermore, in asthmatic patients who do no respond well to corticosteroid therapy [206], the insensitivity to both genomic and nongenomic corticosteroid actions has yet to be established.

\section{Airway blood flow as a biomarker of inflammation}

There is an ongoing search for markers of airway inflammation that can be assessed independently of lung function as an index of disease severity and used to quantitate the response to anti-inflammatory therapy in patients with asthma [207]. Several invasive and noninvasive methods have been used, including the analysis of cellular and acellular components of induced sputum and bronchoalveolar lavage fluid, histological examination of bronchial biopsy specimens, assays of inflammatory serum markers, measurements of the concentrations of exhaled gases (e.g. NO), and inflammatory mediators in exhaled breath condensate. With the advent of a noninvasive method to measure airway blood flow [5, 92], airway hyperperfusion has recently been proposed as a biomarker of asthma-associated inflammation, given that vascular hyperperfusion is a consistent feature of tissue inflammation. Reported reduction of airway blood flow by anti-inflammatory therapy in asthmatics lends support to this concept $[6,93]$.

\section{Tissue bioavailability of inhaled corticosteroids}

The standard in vivo screening test to rank the relative antiinflammatory potencies and tissue bioavailabilities of topical corticosteroids is the McKenzie "skin blanching" test [148]. The test is based on the ability of corticosteroids to cause relatively rapid (within a few hours) vasoconstriction in the skin after topical application [208]. Despite its good correlation with GR binding affinities [209], the McKenzie test is far from ideal to predict the anti-inflammatory potencies of inhaled corticosteroids in asthma. This was demonstrated in a recent study showing no significant correlation between the effects of a 3-week therapy with inhaled budesonide $\left(400 \mu \mathrm{g} \cdot \mathrm{day}^{-1}\right)$ on bronchial hyperreactivity to metacholine, exhaled NO levels, blood eosinophil counts and budesonide's effects on the McKenzie test in patients with asthma [210].

In vivo activity of a corticosteroid is known to depend on the rate and extent to which the drug is absorbed and becomes available at the site of action [211]. This can be tested by measuring airway blood flow responsiveness to inhaled corticosteroids, which seems to be ideal in assessing how these drugs gain access to their sites of actions in the bronchial wall $[29,44]$. Thus, analysis of the rapid vasoconstrictor effect of inhaled corticosteroids can provide detailed information on their airway tissue bioavailability, which depends on the aerosolised drug's physicochemical characteristics and the aerosol-generating device. However, further studies are required to establish a link between the rapid nongenomic vasoconstrictor and the anti-inflammatory effects of inhaled corticosteroids.

\section{Airway conductance}

Airway vascular engorgement, submucosal oedema, and luminal fluid accumulation have all been proposed to contribute to the excessive airway narrowing and airway hyperreactivity in asthmatic subjects. Although the airway vasculature is known to occupy a significant portion of the inner bronchial wall [212, 213], with respect to airway blood and vascular engorgement the reports are conflicting $[78,213-$ 215]. There is less controversy concerning the effect of airway oedema, which narrows the airways by increasing the thickness of the inner bronchial wall and contributes to airway hyperreactivity to the same degree that airway muscle shortening causes greater luminal narrowing compared with the normal airway $[9,216]$.

The immediate impact of inhaled corticosteroids on lung function appears to be marginal in patients with acute asthma $[29,52,53]$. The delayed inhibitory actions on airway hyperaemia, hyperpermeability, oedema formation, and angiogenesis suggest that long-term therapy with inhaled corticosteroids may significantly reduce the size of the vascular compartment, and consequently decrease airflow obstruction. However, these findings have to be confirmed by future studies.

\section{Interactions with inhaled bronchodilators}

The airway circulation has a critical role in the clearance of inhaled drugs from the respiratory tract, and the distribution of systemic drugs to the airway. In asthma, the inflammatory increase in airway blood flow is expected to enhance the clearance and, therefore, decrease the magnitude and duration of the effects of inhaled bronchoactive drugs. In contrast, increased airway blood flow could favour the distribution of systemically administered drugs to the airways. Thus, the 
inflammatory increase in airway blood flow appears to have clinically beneficial, as well as undesirable effects, in the pharmacotherapy of asthma [87].

The corticosteroid-induced decrease in airway blood flow is likely to enhance the action of inhaled bronchodilators by diminishing their clearance from the airway. Although this hypothesis has not yet been directly verified in asthma patients, there is evidence supporting the enhancement of the biological effects of compounds delivered to airways with impaired blood flow [83]. Furthermore, the rapid airway vasoconstriction induced by inhaled budesonide [44] might be responsible for enhancing the bronchodilator action of inhaled formoterol as seen in patients with chronic obstructive pulmonary disease [50]. Since the corticosteroid-induced vasoconstriction peaks rapidly $(\sim 30 \mathrm{~min}$ after drug inhalation), simultaneous administration of inhaled corticosteroids and bronchodilators is likely to be of clinical significance.

\section{CONCLUSIONS}

The complex vascular actions of corticosteroids suggest that asthma-associated angiogenesis, hyperperfusion, hyperpermeability, and leukocyte recruitment are anti-inflammatory targets. The inhibitory effects involve genomic drug actions. The recently demonstrated rapid nongenomic actions of corticosteroids on airway vascular smooth muscle open new avenues for additional interventions in the pharmacotherapy of asthma.

\section{REFERENCES}

1 Jeffery PK. Remodeling and inflammation of bronchi in asthma and chronic obstructive pulmonary disease. Proc Am Thor Soc 2004; 1: 176-183.

2 Charan NB, Baile EM, Pare PD. Bronchial vascular congestion and angiogenesis. Eur Respir J 1997; 10: 1173-1180.

3 McDonald DM. Angiogenesis and remodeling of airway vasculature in chronic inflammation. Am J Respir Crit Care Med 2001; 164: S39-S45.

4 Mitzner W, Wagner EM. Vascular remodeling in the circulations of the lung. J Appl Physiol 2004; 97: 1999-2004.

5 Kumar SD, Emery MJ, Atkins ND, Danta I, Wanner A. Airway mucosal blood flow in bronchial asthma. Am J Respir Crit Care Med 1998; 158: 153-156.

6 Mendes ES, Campos MA, Hurtado A, Wanner A. Effect of montelukast and fluticasone propionate on airway mucosal blood flow in asthma. Am J Respir Crit Care Med 2004; 169: 1131-1134.

7 Kanazawa H, Asai K, Hirata K, Yoshikawa J. Vascular involvement in exercise-induced airway narrowing in patients with bronchial asthma. Chest 2002; 122: 166-170.

8 Kanazawa H, Nomura S, Yoshikawa J. Role of microvascular permeability on physiologic differences in asthma and eosinophilic bronchitis. Am J Respir Crit Care Med 2004; 169: 1125-1130.

9 Brown RH, Zerhouni EA, Mitzner W. Airway edema potentiates airway reactivity. J Appl Physiol 1995; 79: $1242-1248$.
$10 \mathrm{Li} \mathrm{X}$, Wilson JW. Increased vascularity of the bronchial mucosa in mild asthma. Am J Respir Crit Care Med 1997; 156: 229-233.

11 Orsida BE, Li X, Hickey B, Thien F, Wilson JW, Walters EH. Vascularity in asthmatic airways: relation to inhaled steroid dose. Thorax 1999; 54: 289-295.

12 Vrugt B, Wilson S, Bron A, Holgate ST, Djukanovic R, Aalbers R. Bronchial angiogenesis in severe glucocorticoid-dependent asthma. Eur Respir J 2000; 15: 1014-1021.

13 Salvato G. Quantitative and morphological analysis of the vascular bed in bronchial biopsy specimens from asthmatic and non-asthmatic subjects. Thorax 2001; 56: 902-906.

14 Nocker RE, Weller FR, Out TA, de Riemer MJ, Jansen HM, van der Zee JS. A double-blind study on the effect of inhaled corticosteroids on plasma protein exudation in asthma. Am J Respir Crit Care Med 1999; 159: 1499-1505.

15 Hoshino M, Nakamura Y, Hamid QA. Gene expression of vascular endothelial growth factor and its receptors and angiogenesis in bronchial asthma. J Allergy Clin Immunol 2001; 107: 1034-1038.

16 Hoshino M, Takahashi M, Aoike N. Expression of vascular endothelial growth factor, basic fibroblast growth factor, and angiogenin immunoreactivity in asthmatic airways and its relationship to angiogenesis. $J$ Allergy Clin Immunol 2001; 107: 295-301.

17 Chetta A, Zanini A, Foresi A, et al. Vascular component of airway remodeling in asthma is reduced by high dose of fluticasone. Am J Respir Crit Care Med 2003; 167: 751-757.

18 Otani K, Kanazawa H, Fujiwara H, Hirata K, Fujimoto S, Yoshikawa J. Determinants of the severity of exerciseinduced bronchoconstriction in patients with asthma. $J$ Asthma 2004; 41: 271-278.

19 Hench PS, Kendall EC, Slocumb CH, Polley HF. The effect of a hormone of the adrenal cortex (17-hydroxy-11dehydrocorti-costerone, compound E) and of pituitary adrenocorticotropic hormone on rheumatoid arthritis. Proc Staff Meet Mayo Clin 1949; 24: 181-197.

20 McFadden ER Jr. A century of asthma. Am J Respir Crit Care Med 2004; 170: 215-221.

21 Barnes PJ, Chung KF, Page CP. Inflammatory mediators of asthma: an update. Pharmacol Rev 1998; 50: 515-596.

22 De Bosscher K, Vanden Berghe W, Haegeman G. The interplay between the glucocorticoid receptor and nuclear factor-kappaB or activator protein-1: molecular mechanisms for gene repression. Endocr Rev 2003; 24: 488-522.

23 Adcock IM, Ito K, Barnes PJ. Glucocorticoid: effects on gene transcription. Proc Am Thorac Soc 2004; 1: 247-254.

24 Chanez P, Bourdin A, Vachier I, Godard P, Bousquet J, Vignola AM. Effects of inhaled corticosteroids on pathology in asthma and chronic obstructive pulmonary disease. Proc Am Thorac Soc 2004; 1: 184-190.

25 Losel R, Wehling M. Nongenomic actions of steroid hormones. Nature Rev Mol Cell Biol 2003; 4: 46-56.

26 Norman AW, Mizwicki MT, Norman DP. Steroidhormone rapid actions, membrane receptors and a conformational ensemble model. Nat Rev Drug Discov 2004; 3: 27-41. 
27 Watson CS, Gametchu B. Proteins of multiple classes may participate in nongenomic steroid actions. Exp Biol Med 2003; 228: 1272-1281.

28 Bartholome B, Spies CM, Gaber T, et al. Membrane glucocorticoid receptors (mGCR) are expressed in normal human peripheral blood mononuclear cells and upregulated after in vitro stimulation and in patients with rheumatoid arthritis. FASEB J 2004; 18: 70-80.

29 Kumar SD, Brieva JL, Danta I, Wanner A. Transient effect of inhaled fluticasone on airway mucosal blood flow in subjects with and without asthma. Am J Respir Crit Care Med 2000; 161: 918-921.

30 Paredi P, Kharitonov SA, Barnes PJ. Correlation of exhaled breath temperature with bronchial blood flow in asthma. Respir Res 2005; 6: 15.

31 Hayashi R, Wada H, Ito K, Adcock IM. Effects of glucocorticoids on gene transcription. Eur J Pharmacol 2004; 500: 51-62.

32 Karin M. New twists in gene regulation by glucocorticoid receptor: is DNA binding dispensable? Cell 1998; 93: 487-490.

33 Beato M. Gene regulation by steroid hormones. Cell 1989; 56: 335-344.

34 Reichardt HM, Tuckermann JP, Gottlicher M, et al. Repression of inflammatory responses in the absence of DNA binding by the glucocorticoid receptor. EMBO J 2001; 20: 7168-7173.

35 Schacke H, Schottelius A, Docke WD, et al. Dissociation of transactivation from transrepression by a selective glucocorticoid receptor agonist leads to separation of therapeutic effects from side effects. Proc Natl Acad Sci USA 2004; 101: 227-232.

36 Barnes PJ, Karin M. Nuclear factor-kappaB: a pivotal transcription factor in chronic inflammatory diseases. $N$ Engl J Med 1997; 336: 1066-1071.

37 Nguyen C, Teo JL, Matsuda A, et al. Chemogenomic identification of Ref-1/AP-1 as a therapeutic target for asthma. Proc Natl Acad Sci USA 2003; 100: 1169-1173.

38 Barnes PJ. New drugs for asthma. Nat Rev Drug Discov 2004; 3: 831-844.

39 Wilusz CJ, Wilusz J. Bringing the role of mRNA decay in the control of gene expression into focus. Trends Genet 2004; 20: 491-497.

40 Saklatvala J. The p38 MAP kinase pathway as a therapeutic target in inflammatory disease. Curr Opin Pharmacol 2004; 4: 372-377.

41 Clark AR, Lasa M. Crosstalk between glucocorticoids and mitogen-activated protein kinase signalling pathways. Curr Opin Pharmacol 2003; 3: 404-411.

42 Stellato C. Post-transcriptional and nongenomic effects of glucocorticoids. Proc Am Thorac Soc 2004; 1: 255-263.

43 Losel RM, Falkenstein E, Feuring M, et al. Nongenomic steroid action: controversies, questions, and answers. Physiol Rev 2003; 83: 965-1016.

44 Mendes ES, Pereira A, Danta I, Duncan RC, Wanner A. Comparative bronchial vasoconstrictive efficacy of inhaled glucocorticosteroids. Eur Respir J 2003; 21: 989-993.

45 Ketchell RI, Jensen MW, Lumley P, Wright AM, Allenby MI, O'Connor BJ. Rapid effect of inhaled fluticasone propionate on airway responsiveness to adenosine 5'-monophosphate in mild asthma. J Allergy Clin Immunol 2002; 110: 603-606.

46 Thio BJ, Slingerland GL, Nagelkerke AF, Roord JJ, Mulder PG, Dankert-Roelse JE. Effects of single-dose fluticasone on exercise-induced asthma in asthmatic children: a pilot study. Pediatr Pulmonol 2001; 32: 115-121.

47 Tillmann HC, Stuck BA, Feuring M, et al. Delayed genomic and acute nongenomic action of glucocorticosteroids in seasonal allergic rhinitis. Eur J Clin Invest 2004; 34: 67-73.

48 Jeffery J, Garcia J, Avner BP. Corticosteroid potentiation of catecholamine bronchodilator drugs: possible mechanisms of action. Proc West Pharmacol Soc 1979; 22: 149-153.

49 Jeffery JL, Avner BP. Blockade of uptake2: the mechanism of rapid corticosteroid induced potentiation of bronchodilator drugs in tracheal smooth muscle. Proc West Pharmacol Soc 1980; 23: 355-359.

50 Cazzola M, Santus P, Di Marco F, et al. Onset of action of formoterol/budesonide in single inhaler vs. formoterol in patients with COPD. Pulm Pharmacol Ther 2004; 17: 121-125.

51 Rodrigo G, Rodrigo C. Corticosteroids in the emergency department therapy of acute adult asthma: an evidencebased evaluation. Chest 1999; 116: 285-295.

52 Edmonds ML, Camargo CA Jr, Pollack CV Jr, Rowe BH. Early use of inhaled corticosteroids in the emergency department treatment of acute asthma (update of Cochrane Database Syst Rev 2001; CD002308; PMID: 11279763). Cochrane Database of Systematic Reviews 2003; CD002308.

53 Rodrigo GJ, Rodrigo C, Hall JB. Acute asthma in adults: a review. Chest 2004; 125: 1081-1102.

54 Suyemitsu T, Terayama H. Specific binding sites for natural glucocorticoids in plasma membranes of rat liver. Endocrinology 1975; 96: 1499-1508.

55 Orchinik M, Murray TF, Moore FL. A corticosteroid receptor in neuronal membranes. Science 1991; 252: 1848-1851.

56 Gametchu B, Chen F, Sackey F, Powell C, Watson CS. Plasma membrane-resident glucocorticoid receptors in rodent lymphoma and human leukemia models. Steroids 1999; 64: 107-119.

57 Gametchu B, Watson CS, Wu S. Use of receptor antibodies to demonstrate membrane glucocorticoid receptor in cells from human leukemic patients. FASEB J 1993; 7: 1283-1292.

58 Horvath G, Sutto Z, Torbati A, Conner GE, Salathe M, Wanner A. Norepinephrine transport by the extraneuronal monoamine transporter in human bronchial arterial smooth muscle cells. Am J Physiol Lung Cell Mol Physiol 2003; 285: L829-L837.

59 Horvath G, Wanner A. Molecular targets for steroids in airway vascular smooth muscle. Arch Physiol Biochem 2003; 111: 341-344.

60 Horvath G, Lieb T, Conner GE, Salathe M, Wanner A. Steroid sensitivity of norepinephrine uptake by human bronchial arterial and rabbit aortic smooth muscle cells. Am J Respir Cell Mol Biol 2001; 25: 500-506.

61 Makara GB, Haller J. Non-genomic effects of glucocorticoids in the neural system. Evidence, mechanisms and implications. Prog Neurobiol 2001; 65: 367-390. 
62 Evans SJ, Murray TF, Moore FL. Partial purification and biochemical characterization of a membrane glucocorticoid receptor from an amphibian brain. J Steroid Biochem Mol Biol 2000; 72: 209-221.

63 Borski RJ. Nongenomic membrane actions of glucocorticoids in vertebrates. Trends Endocrinol Metab 2000; 11: 427-436.

64 Cato AC, Nestl A, Mink S. Rapid actions of steroid receptors in cellular signaling pathways. Sci STKE 2002; 138: RE9.

65 Buttgereit F, Scheffold A. Rapid glucocorticoid effects on immune cells. Steroids 2002; 67: 529-534.

66 Tumlin JA, Lea JP, Swanson CE, Smith CL, Edge SS, Someren JS. Aldosterone and dexamethasone stimulate calcineurin activity through a transcription-independent mechanism involving steroid receptor-associated heat shock proteins. J Clin Invest 1997; 99: 1217-1223.

67 Croxtall JD, Choudhury Q, Flower RJ. Glucocorticoids act within minutes to inhibit recruitment of signalling factors to activated EGF receptors through a receptor-dependent, transcription-independent mechanism. Br J Pharmacol 2000; 130: 289-298.

68 Hafezi-Moghadam A, Simoncini T, Yang Z, et al. Acute cardiovascular protective effects of corticosteroids are mediated by non-transcriptional activation of endothelial nitric oxide synthase. Nat Med 2002; 8: 473-479.

69 Whiting KP, Restall CJ, Brain PF. Steroid hormoneinduced effects on membrane fluidity and their potential roles in non-genomic mechanisms. Life Sci 2000; 67: 743-757.

70 Buttgereit F. Mechanisms and clinical relevance of nongenomic glucocorticoid actions. Z Rheumatol 2000; 59: Suppl. 2, 119-123.

71 Russell JA, Kircher KW. Metabolism of norepinephrine during nerve stimulation in dog trachea. J Appl Physiol 1985; 59: 1236-1241.

72 Schildkraut JJ, Mooney JJ. Toward a rapidly acting antidepressant: the normetanephrine and extraneuronal monoamine transporter (uptake 2) hypothesis. Am J Psychiatry 2004; 161: 909-911.

73 Widdicombe JG, Webber SE. Neuroregulation and pharmacology of the tracheobronchial circulation. In: Butler J. ed. The bronchial circulation. New York/Basel/ Hong Kong, Marcel Dekker, 1992; pp. 249-289.

74 Deal EC Jr, McFadden ER Jr, Ingram RH Jr, Strauss RH, Jaeger JJ. Role of respiratory heat exchange in production of exercise-induced asthma. J Appl Physiol Resp Environ Exerc Physiol 1979; 46: 467-475.

75 Pinto JM, Assanasen P, Baroody FM, Naureckas E, Solway J, Naclerio RM. Treatment of nasal inflammation decreases the ability of subjects with asthma to condition inspired air. Am J Respir Crit Care Med 2004; 170: 863-869.

76 McFadden ER Jr, Gilbert IA. Exercise-induced asthma. N Engl J Med 1994; 330: 1362-1367.

77 Cabanes L, Costes F, Weber S, et al. Improvement in exercise performance by inhalation of methoxamine in patients with impaired left ventricular function (comment). N Engl J Med 1992; 326: 1661-1665.

78 Csete ME, Abraham WM, Wanner A. Vasomotion influences airflow in peripheral airways. Am Rev Respir Dis 1990; 141: 1409-1413.
79 Blosser S, Mitzner W, Wagner EM. Effects of increased bronchial blood flow on airway morphometry, resistance, and reactivity. J Appl Physiol 1994; 76: 1624-1629.

80 James AL, Pare PD, Hogg JC. The mechanics of airway narrowing in asthma. Am Rev Respir Dis 1989; 139: 242-246.

81 Gallagher SJ, Shank JA, Bochner BS, Wagner EM. Methods to track leukocyte and erythrocyte transit through the bronchial vasculature in sheep. I Immunol Methods 2002; 271: 89-97.

82 Lim LH, Bochner BS, Wagner EM. Leukocyte recruitment in the airways: an intravital microscopic study of rat tracheal microcirculation. Am J Physiol Lung Cell Mol Physiol 2002; 282: L959-L967.

83 Kelly L, Kolbe J, Mitzner W, Spannhake EW, BrombergerBarnea B, Menkes H. Bronchial blood flow affects recovery from constriction in dog lung periphery. $J$ Appl Physiol 1986; 60: 1954-1959.

84 Csete ME, Chediak AD, Abraham WM, Wanner A. Airway blood flow modifies allergic airway smooth muscle contraction. Am Rev Respir Dis 1991; 144: 59-63.

85 Wagner EM, Foster WM. Interdependence of bronchial circulation and clearance of 99mTc-DTPA from the airway surface. J Appl Physiol 2001; 90: 1275-1281.

86 Wanner A. Circulation of the airway mucosa. J Appl Physiol 1989; 67: 917-925.

87 Wanner A. Clinical perspectives: role of the airway circulation in drug therapy. J Aerosol Med 1996; 9: 19-23.

88 Long WM, Yerger LD, Martinez H, et al. Modification of bronchial blood flow during allergic airway responses. $J$ Appl Physiol 1988; 65: 272-282.

89 Long WM, Yerger LD, Abraham WM, Lobel C. Latephase bronchial vascular responses in allergic sheep. $J$ Appl Physiol 1990; 69: 584-590.

90 Wanner A, Chediak AD, Csete ME. Airway mucosal blood flow: response to autonomic and inflammatory stimuli. Eur Respir J 1990; 3: Suppl. 12, 618s-623s.

91 Onorato DJ, Demirozu MC, Breitenbucher A, Atkins ND, Chediak AD, Wanner A. Airway mucosal blood flow in humans. Response to adrenergic agonists. Am J Respir Crit Care Med 1994; 149: 1132-1137.

92 Scuri M, McCaskill V, Chediak AD, Abraham WM, Wanner A. Measurement of airway mucosal blood flow with dimethylether: validation with microspheres. J Appl Physiol 1995; 79: 1386-1390.

93 Brieva JL, Danta I, Wanner A. Effect of an inhaled glucocorticosteroid on airway mucosal blood flow in mild asthma. Am J Respir Crit Care Med 2000; 161: 293-296.

94 Brieva J, Wanner A. Adrenergic airway vascular smooth muscle responsiveness in healthy and asthmatic subjects. J Appl Physiol 2001; 90: 665-669.

95 Joos GF, Germonpre PR, Pauwels RA. Role of tachykinins in asthma. Allergy 2000; 55: 321-337.

96 Sylvin H, Weitzberg E, Alving K. Endothelin-induced vascular and bronchial effects in pig airways: role in acute allergic responses. J Appl Physiol 2002; 93: 1608-1615.

97 Wagner EM. TNF-alpha induced bronchial vasoconstriction. Am J Physiol Heart Circ Physiol 2000; 279: H946-H951. 
98 Barker JA, Chediak AD, Baier HJ, Wanner A. Tracheal mucosal blood flow responses to autonomic agonists. J Appl Physiol 1988; 65: 829-834.

99 Zschauer AO, Sielczak MW, Wanner A. Altered contractile sensitivity of isolated bronchial artery to phenylephrine in ovalbumin-sensitized rabbits. J Appl Physiol 1999; 86: $1721-1727$.

100 Carvalho P, Thompson WH, Charan NB. Comparative effects of alpha-receptor stimulation and nitrergic inhibition on bronchovascular tone. J Appl Physiol 2000; 88: 1685-1689.

101 Henderson WR, Shelhamer JH, Reingold DB, Smith LJ, Evans R 3rd, Kaliner M. Alpha-adrenergic hyper-responsiveness in asthma. N Engl J Med 1979; 300: 642-647.

102 Barnes PJ, Dollery CT, MacDermot J. Increased pulmonary alpha-adrenergic and reduced beta-adrenergic receptors in experimental asthma. Nature 1980; 285: 569-571.

103 Horvath G, Torbati A, Conner GE, Salathe M, Wanner A. Systemic ovalbumin sensitization downregulates norepinephrine uptake by rabbit aortic smooth muscle cells. Am J Respir Cell Mol Biol 2002; 27: 746-751.

104 Charan NB, Johnson SR, Lakshminarayan S, Thompson WH, Carvalho P. Nitric oxide and betaadrenergic agonist-induced bronchial arterial vasodilation. J Appl Physiol 1997; 82: 686-692.

105 Carvalho P, Johnson SR, Charan NB. Non-cAMPmediated bronchial arterial vasodilation in response to inhaled beta-agonists. J Appl Physiol 1998; 84: 215-221.

106 Pereira A, Mendes E, Ferreira T, Wanner A. Effect of inhaled racemic and (R)-albuterol on airway vascular smooth muscle tone in healthy and asthmatic subjects. Lung 2003; 181: 201-211.

107 Liu MC, Hubbard WC, Proud D, et al. Immediate and late inflammatory responses to ragweed antigen challenge of the peripheral airways in allergic asthmatics. Cellular, mediator, and permeability changes. Am Rev Respir Dis 1991; 144: 51-58.

108 Svensson C, Gronneberg R, Andersson M, et al. Allergen challenge-induced entry of alpha 2-macroglobulin and tryptase into human nasal and bronchial airways. $J$ Allergy Clin Immunol 1995; 96: 239-246.

109 Greiff L, Andersson M, Erjefalt JS, Persson CG, Wollmer P. Airway microvascular extravasation and luminal entry of plasma. Clin Physiol Func Imaging 2003; 23: 301-306.

110 McDonald DM. Endothelial gaps and permeability of venules in rat tracheas exposed to inflammatory stimuli. Am J Physiol 1994; 266: L61-L83.

111 Baluk P, Bolton P, Hirata A, Thurston G, McDonald DM. Endothelial gaps and adherent leukocytes in allergeninduced early- and late-phase plasma leakage in rat airways. Am J Pathol 1998; 152: 1463-1476.

112 McDonald DM, Thurston G, Baluk P. Endothelial gaps as sites for plasma leakage in inflammation. Microcirculation 1999; 6: 7-22.

113 Goldie RG, Pedersen KE. Mechanisms of increased airway microvascular permeability: role in airway inflammation and obstruction. Clin Exp Pharmacol Physiol 1995; 22: 387-396.
114 Persson CG, Erjefalt JS, Greiff L, et al. Plasma-derived proteins in airway defence, disease and repair of epithelial injury. Eur Respir J 1998; 11: 958-970.

115 Greiff L, Wollmer P, Andersson M, Svensson C, Persson CG. Effects of formoterol on histamine induced plasma exudation in induced sputum from normal subjects. Thorax 1998; 53: 1010-1013.

116 Greiff L, Erjefalt I, Erjefalt JS, Wollmer P, Sundler F, Persson CG. Effects of topical platelet activating factor on the guinea-pig tracheobronchial mucosa in vivo. Acta Physiol Scand 1997; 160: 387-391.

117 Erjefalt I, Persson CG. Pharmacologic control of plasma exudation into tracheobronchial airways. Am Rev Respir Dis 1991; 143: 1008-1014.

118 Damazo AS, Tavares de Lima W, Perretti M, Oliani SM. Pharmacological modulation of allergic inflammation in the rat airways and association with mast cell heterogeneity. Eur J Pharmacol 2001; 426: 123-130.

119 Ferrara N. Vascular endothelial growth factor: basic science and clinical progress. Endocr Rev 2004; 25: 581-611.

120 Asai K, Kanazawa H, Kamoi H, Shiraishi S, Hirata K, Yoshikawa J. Increased levels of vascular endothelial growth factor in induced sputum in asthmatic patients. Clin Exp Allergy 2003; 33: 595-599.

121 Kanazawa H, Hirata K, Yoshikawa J. Involvement of vascular endothelial growth factor in exercise induced bronchoconstriction in asthmatic patients. Thorax 2002; 57: 885-888.

122 Rogers DF, Belvisi MG, Aursudkij B, Evans TW, Barnes PJ. Effects and interactions of sensory neuropeptides on airway microvascular leakage in guinea-pigs. $\mathrm{Br}$ J Pharmacol 1988; 95: 1109-1116.

123 McDonald DM, Bowden JJ, Baluk P, Bunnett NW. Neurogenic inflammation. A model for studying efferent actions of sensory nerves. Adv Exp Med Biol 1996; 410: 453-462.

124 Halldorsdottir H, Greiff L, Wollmer P, et al. Effects of inhaled histamine, methacholine and capsaicin on sputum levels of alpha 2-macroglobulin. Thorax 1997; 52: 964-968.

125 Erjefalt I, Persson CG. Effects of adrenaline and terbutaline on mediator-increased vascular permeability in the cat trachea. Br J Pharmacol 1982; 77: 399.

126 Luster AD. Chemokines - chemotactic cytokines that mediate inflammation. N Engl J Med 1998; 338: 436-445.

127 Luster AD, Tager AM. T-cell trafficking in asthma: lipid mediators grease the way. Nat Rev Immunol 2004; 4: 711-724.

128 Ulbrich H, Eriksson EE, Lindbom L. Leukocyte and endothelial cell adhesion molecules as targets for therapeutic interventions in inflammatory disease. Trends Pharmacol Sci 2003; 24: 640-647.

129 Butcher EC. Leukocyte-endothelial cell recognition: three (or more) steps to specificity and diversity. Cell 1991; 67: 1033-1036.

130 Wagner JG, Roth RA. Neutrophil migration mechanisms, with an emphasis on the pulmonary vasculature. Pharmacol Rev 2000; 52: 349-374.

131 Virchow R. Gesammelte Werke. In: Abhandlungen zur Wissenschlaftlichen Medizin. Frankfurt, Meidinger 1856; pp. 285-286. 
132 Cudkowicz L. Leonardo da Vinci and the bronchial circulation. Br J Dis Chest 1953; 47: 23-30.

133 Guillot N. Recherches anatomiques et pathologiques sur les amas de charbon products pendant la vie dans les organes respiratories de l'homme. Arch Gen Med 1845; 7: 151-284.

134 Folkman J. Tumor angiogenesis: therapeutic implications. N Engl J Med 1971; 285: 1182-1186.

135 Wilson J. The bronchial microcirculation in asthma. Clin Exp Allergy 2000; 30: Suppl. 1, 51-53.

136 Woods DA, Miller M. The role of the dual pulmonary circulation in various pathologic conditions of the lung. $J$ Thorac Surg 1938; 7: 649-670.

137 Dunnill MS. The pathology of asthma with special reference to changes in the bronchial mucosa. J Clin Pathol 1960; 13: 27-33.

138 Carroll NG, Cooke C, James AL. Bronchial blood vessel dimensions in asthma. Am J Respir Crit Care Med 1997; 155: 689-695.

139 Hoshino M, Takahashi M, Takai Y, Sim J, Aoike N. Inhaled corticosteroids decrease vascularity of the bronchial mucosa in patients with asthma. Clin Exp Allergy 2001; 31: 722-730.

140 Hoshino M, Aoike N, Takahashi M, Nakamura Y, Nakagawa T. Increased immunoreactivity of stromal cell-derived factor-1 and angiogenesis in asthma. Eur Respir J 2003; 21: 804-809.

141 Tanaka H, Yamada G, Saikai $T$, et al. Increased airway vascularity in newly diagnosed asthma using a highmagnification bronchovideoscope. Am J Respir Crit Care Med 2003; 168: 1495-1499.

142 Yancopoulos GD, Davis S, Gale NW, Rudge JS, Wiegand SJ, Holash J. Vascular-specific growth factors and blood vessel formation. Nature 2000; 407: 242-248.

143 Baluk P, Lee CG, Link H, et al. Regulated angiogenesis and vascular regression in mice overexpressing vascular endothelial growth factor in airways. Am J Pathol 2004; 165: 1071-1085.

144 Lee CG, Link H, Baluk $P$, et al. Vascular endothelial growth factor (VEGF) induces remodeling and enhances TH2-mediated sensitization and inflammation in the lung. Nat Med 2004; 10: 1095-1103.

145 Dahlqvist A, Umemoto EY, Brokaw JJ, Dupuis M, McDonald DM. Tissue macrophages associated with angiogenesis in chronic airway inflammation in rats. Am J Respir Cell Mol Biol 1999; 20: 237-247.

146 Baluk P, Raymond WW, Ator E, Coussens LM, McDonald DM, Caughey GH. Matrix metalloproteinase2 and -9 expression increases in Mycoplasma-infected airways but is not required for microvascular remodeling. Am J Physiol Lung Cell Mol Physiol 2004; 287: L307-L317.

147 Redington AE, Roche WR, Madden J, et al. Basic fibroblast growth factor in asthma: measurement in bronchoalveolar lavage fluid basally and following allergen challenge. J Allergy Clin Immunol 2001; 107: 384-387.

148 McKenzie AW, Stoughton RB. Method for comparing percutaneous absorption of steroids. Arch Dermatol 1962; 86: $608-610$
149 Shishido H, Kikuchi S, Heckman H, Myers RR. Dexamethasone decreases blood flow in normal nerves and dorsal root ganglia. Spine 2002; 27: 581-586.

150 Ginsburg J. Influence of intra-arterial hydrocortisone on adrenergic responses in the hand. BMJ 1958; 424-427.

151 Kalsner S. Sensitization of noradrenaline responses by inhibitors of extraneuronal uptake in a coronary artery preparation. Br J Pharmacol 1974; 51: 453-455.

152 Ohkubo H, Chiba S. Vascular responses of ophthalmic arteries to exogenous and endogenous norepinephrine. Exp Eye Res 1989; 48: 539-547.

153 Wanner A, Horvath G, Brieva JL, Kumar SD, Mendes ES. Nongenomic actions of glucocorticosteroids on the airway vasculature in asthma. Proc Am Thor Soc 2004; 1 235-238.

154 Annane D, Bellissant E, Sebille V, et al. Impaired pressor sensitivity to noradrenaline in septic shock patients with and without impaired adrenal function reserve. $\mathrm{Br} J \mathrm{Clin}$ Pharmacol 1998; 46: 589-597.

155 Fritz I, Levine R. Action of adrenal cortical steroids and norepinephrine on vascular responses of stress in adrenalectomized rats. Am J Physiol 1951; 165: 456-465.

156 Eisenhofer G. The role of neuronal and extraneuronal plasma membrane transporters in the inactivation of peripheral catecholamines. Pharmacol Ther 2001; 91: 35-62.

157 Schlaich MP, Lambert E, Kaye DM, et al. Sympathetic augmentation in hypertension: role of nerve firing, norepinephrine reuptake, and angiotensin neuromodulation. Hypertension 2004; 43: 169-175.

158 Iversen LL, Salt PJ. Inhibition of catecholamine uptake-2 by steroids in the isolated rat heart. Br I Pharmacol 1970; 40: 528-530.

159 Chan CC, Kalsner S. Termination of responses to sympathetic nerve stimulation and to noradrenaline in a perfused arterial preparation: the role of neuronal and extraneuronal uptake. J Pharmacol Exp Ther 1982; 222. 731-740.

160 Kalsner S. Role of extraneuronal mechanisms in the termination of contractile responses to amines in vascular tissue. Br J Pharmacol 1975; 53: 267-277.

161 Koepsell H. Polyspecific organic cation transporters: their functions and interactions with drugs. Trends Pharmacol Sci 2004; 25: 375-381.

162 Steiner A, Locher R, Sachinidis A, Vetter W. Cortisolstimulated phosphoinositide metabolism in vascular smooth muscle cells: a role for glucocorticoids in blood pressure control? J Hypertens Suppl. 6, 1989; 7: S140-S141.

163 Muto S, Ebata S, Okada K, Saito T, Asano Y. Glucocorticoid modulates $\mathrm{Na}^{+} / \mathrm{H}^{+}$exchange activity in vascular smooth muscle cells by nongenomic and genomic mechanisms. Kidney Int 2000; 57: 2319-2333.

164 Wehling M, Neylon CB, Fullerton M, Bobik A, Funder JW Nongenomic effects of aldosterone on intracellular $\mathrm{Ca}^{2+}$ in vascular smooth-muscle cells. Circ Res 1995; 76: 973-979.

165 Pitzalis C, Pipitone N, Perretti M. Regulation of leukocyte-endothelial interactions by glucocorticoids. Ann N Y Acad Sci 2002; 966: 108-118.

166 Goulding NJ. The molecular complexity of glucocorticoid actions in inflammation - a four-ring circus. Curr Opin Pharmacol 2004; 4: 629-636. 
167 Hinz B, Hirschelmann R. Dexamethasone megadoses stabilize rat liver lysosomal membranes by non-genomic and genomic effects. Pharm Res 2000; 17: 1489-1493.

168 Croxtall JD, van Hal PT, Choudhury Q, Gilroy DW, Flower RJ. Different glucocorticoids vary in their genomic and non-genomic mechanism of action in A549 cells. Br J Pharmacol 2002; 135: 511-519.

169 Schmid D, Burmester GR, Tripmacher R, Kuhnke A, Buttgereit F. Bioenergetics of human peripheral blood mononuclear cell metabolism in quiescent, activated, and glucocorticoid-treated states. Biosci Rep 2000; 20: 289-302.

170 Baccan GC, Oliveira RDR, Mantovani B. Stress and immunological phagocytosis: possible nongenomic action of corticosterone. Life Sci 2004; 75: 1357-1368.

171 Long F, Wang YX, Liu L, Zhou J, Cui RY, Jiang CL. Rapid nongenomic inhibitory effects of glucocorticoids on phagocytosis and superoxide anion production by macrophages. Steroids 2005; 70: 55-61.

172 Liu L, Wang YX, Zhou J, et al. Rapid non-genomic inhibitory effects of glucocorticoids on human neutrophil degranulation. Inflamm Res 2005; 54: 37-41.

173 Ullian ME. The role of corticosteriods in the regulation of vascular tone. Cardiovasc Res 1999; 41: 55-64.

174 Perretti M, Ahluwalia A. The microcirculation and inflammation: site of action for glucocorticoids. Microcirculation 2000; 7: 147-161.

175 Yang S, Zhang L. Glucocorticoids and vascular reactivity. Curr Vasc Pharmacol 2004; 2: 1-12.

176 Busse W, Banks-Schlegel S, Noel P, et al. Future research directions in asthma: an NHLBI Working Group report. Am J Respir Crit Care Med 2004; 170: 683-690.

177 Sakaue M, Hoffman BB. Glucocorticoids induce transcription and expression of the alpha $1 \mathrm{~B}$ adrenergic receptor gene in DTT1 MF-2 smooth muscle cells. J Clin Invest 1991; 88: 385-389.

178 Smith L, Smith JB. Regulation of sodium-calcium exchanger by glucocorticoids and growth factors in vascular smooth muscle. J Biol Chem 1994; 269: 27527-27531.

179 Sato A, Suzuki H, Murakami M, Nakazato Y, Iwaita Y, Saruta T. Glucocorticoid increases angiotensin II type 1 receptor and its gene expression. Hypertension 1994; 23 : 25-30.

180 Brem AS, Bina RB, Mehta S, Marshall J. Glucocorticoids inhibit the expression of calcium-dependent potassium channels in vascular smooth muscle. Mol Genet Metab 1999; 67: 53-57.

181 Murasawa S, Matsubara H, Kizima K, Maruyama K, Mori Y, Inada M. Glucocorticoids regulate V1a vasopressin receptor expression by increasing mRNA stability in vascular smooth muscle cells. Hypertension 1995; 26: 665-669.

182 Nuglozeh E, Mbikay M, Stewart DJ, Legault L. Rat natriuretic peptide receptor genes are regulated by glucocorticoids in vitro. Life Sci 1997; 61: 2143-2155.

183 Fishel RS, Eisenberg S, Shai SY, Redden RA, Bernstein KE, Berk BC. Glucocorticoids induce angiotensin-converting enzyme expression in vascular smooth muscle. Hypertension 1995; 25: 343-349.
184 Provencher PH, Villeneuve A, Morin C. Glucocorticoids increase preproendothelin-1 expression in rat aorta. Endocr Res 1998; 24: 737-741.

185 Muto S, Nemoto J, Ebata S, Kawakami K, Asano Y. Corticosterone and 11-dehydrocorticosterone stimulate $\mathrm{Na}, \mathrm{K}-\mathrm{ATPase}$ gene expression in vascular smooth muscle cells. Kidney Int 1998; 54: 492-508.

186 Mendelsohn FA, Lloyd CJ, Kachel C, Funder JW. Induction by glucocorticoids of angiotensin converting enzyme production from bovine endothelial cells in culture and rat lung in vivo. J Clin Invest 1982; 70: 684-692.

187 Wallerath T, Witte K, Schafer SC, et al. Down-regulation of the expression of endothelial NO synthase is likely to contribute to glucocorticoid-mediated hypertension. Proc Natl Acad Sci USA 1999; 96: 13357-13362.

188 Schafer SC, Wallerath T, Closs EI, et al. Dexamethasone suppresses eNOS and CAT-1 and induces oxidative stress in mouse resistance arterioles. Am J Physiol Heart Circ Physiol 2005; 288: H436-H444.

189 Lewis GD, Campbell WB, Johnson AR. Inhibition of prostaglandin synthesis by glucocorticoids in human endothelial cells. Endocrinology 1986; 119: 62-69.

190 Inoue $H$, Umesono K, Nishimori T, Hirata $Y$, Tanabe T. Glucocorticoid-mediated suppression of the promoter activity of the cyclooxygenase- 2 gene is modulated by expression of its receptor in vascular endothelial cells. Biochem Biophys Res Commun 1999; 254: 292-298.

191 Iuchi T, Akaike M, Mitsui T, et al. Glucocorticoid excess induces superoxide production in vascular endothelial cells and elicits vascular endothelial dysfunction. Circ Res 2003; 92: 81-87.

192 Kalavantavanich K, Schramm CM. Dexamethasone potentiates high-affinity beta-agonist binding and g(s)alpha protein expression in airway smooth muscle. Am J Physiol Lung Cell Mol Physiol 2000; 278: L1101-L1106.

193 Kornel L, Prancan AV, Kanamarlapudi N, Hynes J, Kuzianik E. Study on the mechanisms of glucocorticoidinduced hypertension - glucocorticoids increase transmembrane $\mathrm{Ca} 2+$ influx in vascular smooth-muscle invivo. Endocr Res 1995; 21: 203-210.

194 Xiao D, Huang X, Bae S, Ducsay CA, Zhang L. Cortisolmediated potentiation of uterine artery contractility: effect of pregnancy. Am J Physiol Heart Circ Physiol 2002; 283: $\mathrm{H} 238-\mathrm{H} 246$.

195 Piedimonte G, McDonald DM, Nadel JA. Glucocorticoids inhibit neurogenic plasma extravasation and prevent virus-potentiated extravasation in the rat trachea. J Clin Invest 1990; 86: 1409-1415.

196 Schoonbrood DFM, Out TA, Lutter R, Reimert CM, Vanoverveld FJ, Jansen HM. Plasma-protein leakage and local secretion of proteins assessed in sputum in asthma and COPD - the effect of inhaled corticosteroids. Clin Chim Acta 1995; 240: 163-178.

197 Vandegraaf EA, Out TA, Roos CM, Jansen HM. Respiratory membrane-permeability and bronchial hyperreactivity in patients with stable asthma - effects of therapy with inhaled steroids. Am Rev Respir Dis 1991; 143: 362-368.

198 Piedimonte G, McDonald DM, Nadel JA. Neutral endopeptidase and kininase II mediate glucocorticoid 
inhibition of neurogenic inflammation in the rat trachea. $J$ Clin Invest 1991; 88: 40-44.

199 Cronstein BN, Kimmel SC, Levin RI, Martiniuk F, Weissmann G. A mechanism for the antiinflammatory effects of corticosteroids - the glucocorticoid receptor regulates leukocyte adhesion to endothelial-cells and expression of endothelial leukocyte adhesion molecule-1 and intercellular-adhesion molecule-1. Proc Natl Acad Sci USA 1992; 89: 9991-9995.

200 Cengizlier R, Demirpolat E, Tulek N, Cakmak F. Circulating ICAM-1 levels in bronchial asthma and the effect of inhaled corticosteroids. Ann Allergy Asthma Immunol 2000; 84: 539-541.

201 Pipitone N, Sinha M, Theodoridis E, et al. The glucocorticoid inhibition of LFA-1 and CD2 expression by human mononuclear cells is reversed by IL-2, IL-7 and IL-15. Eur J Immunol 2001; 31: 2135-2142.

202 Hakonarson H, Halapi E, Whelan R, Gulcher J,Stefansson K, Grunstein MM. Association between IL-1beta/TNFalpha-induced glucocorticoid-sensitive changes in multiple gene expression and altered responsiveness in airway smooth muscle. Am J Respir Cell Mol Biol 2001; 25: 761-771.

203 Lange P, Parner J, Vestbo J, Schnohr P, Jensen GA. 15year follow-up study of ventilatory function in adults with asthma. N Engl J Med 1998; 339: 1194-1200.

204 Boulet LP, Laviolette M, Turcotte $\mathrm{H}$, et al. Bronchial subepithelial fibrosis correlates with airway responsiveness to methacholine. Chest 1997; 112: 45-52.

205 Orsida BE, Ward C, Li X, et al. Effect of a long-acting beta2-agonist over three months on airway wall vascular remodeling in asthma. Am J Respir Crit Care Med 2001; 164: 117-121.

206 Adcock IM, Lane SJ. Corticosteroid-insensitive asthma: molecular mechanisms. J Endocrinol 2003; 178: 347-355.
207 Kharitonov SA, Barnes PJ. Effects of corticosteroids on noninvasive biomarkers of inflammation in asthma and chronic obstructive pulmonary disease. Proc Am Thor Soc 2004; 1: 191-199.

208 Noon JP, Evans CE, Haynes WG, Webb DJ, Walker BR. A comparison of techniques to assess skin blanching following the topical application of glucocorticoids. $\mathrm{Br} \mathrm{J}$ Dermatol 1996; 134: 837-842.

209 Johnson M. Pharmacodynamics and pharmacokinetics of inhaled glucocorticoids. J Allergy Clin Immunol 1996; 97: 169-176.

210 Wilson AM, Coutie WJ, Sims EJ, Lipworth BJ. The skin vasoconstrictor assay does not correlate significantly to airway or systemic responsiveness to inhaled budesonide in asthmatic patients. Eur J Clin Pharmacol 2003; 58: 643-647.

211 Hammond GL. Determinants of steroid hormone bioavailability. Biochem Soc Trans 1997; 25: 577-582.

212 Mariassy AT, Gazeroglu H, Wanner A. Morphometry of the subepithelial circulation in sheep airways. Effect of vascular congestion. Am Rev Respir Dis 1991; 143: 162-166.

213 Baile EM, Sotres-Vega A, Pare PD. Airway blood flow and bronchovascular congestion in sheep. Eur Respir J 1994; 7: 1300-1307.

214 Cabanes LR, Weber SN, Matran R, et al. Bronchial hyperresponsiveness to methacholine in patients with impaired left ventricular function. N Engl J Med 1989; 320: 1317-1322.

215 Wagner EM, Mitzner W. Effects of bronchial vascular engorgement on airway dimensions. J Appl Physiol 1996; 81: 293-301.

216 Pellegrino R, Dellaca R, Macklem PT, et al. Effects of rapid saline infusion on lung mechanics and airway responsiveness in humans. J Appl Physiol 2003; 95: 728-734. 